Agata Hiacynta TaRnacka

Uniwersytet Jagieloński

agata.tarnacka@gmail.com

ORCID: 0000-0003-0003-4748

\title{
LEGAL STATUS AND COMPETENCES OF BODIES of the National Bank of Poland
}

\begin{abstract}
The subject of consideration of the article titled Organization and operation of the National Bank of Poland are legal acts that are the basis for the organization and operation of the National Bank of Poland. The first part of the article presents the regulations contained in the Constitution of the Republic of Poland and in the Act on the National Bank of Poland relating to the functioning of the financial institution in question. The second part of the article covered the appointment and functions of the organs of the National Bank of Poland with an indication of the possibility of their cancellation. The aim of the analysis was to present the current state of the organization and operation of the National Bank of Poland and postulates regarding changes that could strengthen its position as an institution implementing monetary policy.
\end{abstract}

KEYWORDS: polish national bank, monetary policy council

\section{INTRODUCTION}

The subject of the article titled Organization and operation of the National Bank of Poland are legal acts that are the basis for the organization and operation of the National Bank of Poland. The article presents the regulations contained in the Constitution of the Republic of Poland of $2^{\text {ed }}$ April , 1997 (Journal of Law of 1997 No. 78, item 483, as amended) and in the Act on the National Bank of Poland of 29st August, 1997 (Journal of Laws of 1997 No. 140, item 938, as amended) relating to the functioning of the financial institution in question. An analysis of legal provisions regulating 
the appointment and functions of the organs of the National Bank of Poland with an indication of the possibility of their cancellation was also undertaken. The aim of the analysis was to present the current state of the organization and operation of the National Bank of Poland and postulates regarding changes that could strengthen its position as an institution implementing monetary policy.

\section{Constitution OF THE REPUBLIC OF POLAND ON $2^{\text {ED }}$ APRIL 1997}

The Constitution of each state should include the principles of the socio-economic system. Until 1992, the Constitution of the Polish People's Republic (Journal of Law of 1952, no 33, item 232) in force adopted by the Legislative Sejm on $22^{\text {ed }}$ July, 1952, which introduced the socialist system, was in force in Poland. It was developed in its original form according to the Stalinist formula of the USSR constitution of 1936. The system of the market economy found its place only in the Small Constitution of 1952. When President Lech Wałęsa signed the Small Constitution (Journal of Law of 1992, no 84, item 426) on $17^{\text {st }}$ October, 1992, the provisions of the Constitution of the Polish People's Republic of 1952 regarding the socialist system and new ones, constituting the basis of the political system and market economy, were repealed. However, this was an incomplete Constitution and was adopted as a temporary legal regulation due to the prolonged project work on the new Basic Law.

The new Constitution of the Republic of Poland (Journal of Law of 1997, no 78, item 483) was adopted by the National Assembly on $2^{\text {ed }}$ April, 1997. In the constitutional referendum held on $25^{\text {st }}$ May, 1997, where the majority of those participating in the vote opted for the new basic law. After the recognition of the validity of the referendum by the Supreme Court, the Constitution of the Republic of Poland was officially signed by President Aleksander Kwaśniewski on $16^{\text {st }}$ July, 1997. This act came into force on $17^{\text {st }}$ October, 1997. Article 20 in Chapter I of the Constitution provides that the basis of the economic system of the Republic of Poland is the social market economy based on freedom of economic activity, private property and solidarity, dialogue and cooperation of social partners (Kosikowski, 1997, p. 149). 
The group of nearly thirty articles of the Constitution refers to financial issues (Kosikowski, 1997, p. 156). Among these provisions is an article directly concerning the National Bank of Poland. Speech on art. 227 in Chapter X Public finance. What is particularly noteworthy is the fact that for the first time in Poland, the central bank has been given the rank of a constitutional state body (Mikos, p. 87). In addition, the provisions of the Constitution have strengthened the independence of the NBP, which, without the participation of the Sejm, is to set and implement the monetary policy of the state. In art. 227 par. 1, a provision stating that the NBP has the exclusive right to issue money and to determine and implement monetary policy. However, this exclusivity only applies to the issue of money, not to the determination and implementation of monetary policy. For "the second sentence of art. 227 ("It has [the NBP] exclusive right to issue money and to determine and implement monetary policy") consists of two parts connected by inter-conjunction conjunction "and". Exclusivity was reserved only in the first part of the sentence regarding the issue of money. In the second part, after the conjunction "and", there is no reimbursement of granting the NBP the exclusive right to determine and implement monetary policy" (Tupin, p. 2).

The Constitution also introduced changes in the manner of managing the bank, strengthening the position of the NBP. The basic law mentions three central bank bodies: the President of the NBP, the Monetary Policy Council and the NBP Management Board. Along with the adoption of the Constitution, a new NBP body - the Monetary Policy Council - was created, which was to establish the monetary policy assumptions every year. The members of the Council included: the President of the NBP, members appointed by the President, the Sejm and the Senate. As the years went by, the NBP became a central bank that presented high European quality, while the Monetary Policy Council proved to be an effective body shaping the monetary policy of the state. However, the separation of bodies and the definition of NBP's functions in constitutional provisions are criticized in the literature. As the authors think, it may lead to difficulties in introducing changes concerning the functioning of the central bank (Kosikowski, 1997, p. 161). 


\section{ACt on the NATional POLISH BANK OF 29 AUGUST 1997}

According to art. 227 par. 7 of the Constitution, the organization and principles of the NBP's operation as well as detailed rules for appointing and dismissing its organs are specified in the Act. In response to this legal regulation, on $29^{\text {st }}$ August 1997 the Act on the National Bank of Poland was passed (Journal of Law of 1997 r. no 140, item 9380). This Act consists of 76 articles in 11 chapters: General provisions, NBP Organization, NBP and state authorities, Banking supervision (deleted), Issues of cash, Monetary policy instruments, Keeping bank accounts, Foreign exchange activity, Special obligations and powers of the NBP, The financial management of the NBP, Transitional and final provisions.

In the first article, the act stipulates that the NBP is the central bank of the Republic of Poland. It is a kind of a repetition of the constitutional provision. In art. 3 this legal act indicates the NBP objectives and tasks. Thus, "the basic objective of the NBP's activity is to maintain a stable price level, while supporting the Government's economic policy, as long as it does not limit the basic objective of the NBP." The central bank's tasks included running a banking service for the state budget. The NBP does not have a specific monopoly for servicing all public finances, but it is obliged to operate cash register of state finances (Zubik, p. 38-39). In the scope of the NBP organization, the Act, apart from the repeats from the Constitution, defines a detailed procedure for appointing and dismissing NBP bodies, their tasks and competences (Niemierka, p. 8).

Many authors addressed the subject of the NBP's legal nature and related dilemmas (Myślak, p. 55-60). The NBP is a state legal person (Tupin, p. 2). However, it has a legal personality not subject to entry in the register of state-owned enterprises (Mikos, p. 88). “The NBP is [...] a bank, and this is neither an office nor a classic entrepreneur. What is more, the NBP is not an operational bank, although it also performs certain operational activities (eg maintenance of bank accounts, granting refinancing loans, granting guarantees and sureties). Therefore, it is not subject to the general rules of banking activity set out in the Banking Law Act. It is the central bank of the state, which commonly means a situation separate from other 
banks and other legal entities. Therefore, any comparisons of the NBP's position with other entities are not eligible and thus become sterile. What is important, however, is whether the NBP's organizational and legal form guarantees independence from the government and allows it to fulfill the function of the central bank of the state. It is also a global problem" (Kosikowski, 2002, p. 15).

\section{Bodies of The National Bank of Poland}

The Constitution in art. 227 par. 2 and art. 6 of the Act on the NBP stipulate that the NBP bodies are: the President of the NBP, the Monetary Policy Council and the Management Board of the NBP. The constitution lists the organs, but does not indicate their competence. This task was passed to the legislator in art. 227 par. 7 of the Basic Law. The Act on the NBP replaced the one-man management exercised by the President of the NBP, collegial management (the Monetary Policy Council and the NBP Management Board) (Mikos, p. 92). Since then, the actual power division of the central bank functions (Myślak, p. 54). It is worth noting that the President of the NBP is the chairman of both the Monetary Policy Council and the NBP Management Board.

\section{President OF THE NBP}

The President of the NBP is the superior of all NBP employees. The rights and obligations of NBP employees are set out in the Labor Code and business pragmatics specified in a separate act (Art. 11 par. 1 NBP Act). The President of the NBP may not belong to a political party, a trade union or perform public activities which would constitute an obstacle to the exercise of his office (Art. 227 ust. 4 NBP Act). The Act on the NBP provides for competences and appointment of the President of the NBP in art. 9-11. So far, the President of the National Bank of Poland has been six people since 1989: Władysław Baka, Grzegorz Wójtowicz, Hanna Gronkiewicz-Waltz (two terms), Leszek Balcerowicz, Sławomir Skrzypek and Marek Belka. Up to now, there were also two people who were the President of the National Bank of Poland: Andrzej Topiński for less than seven months and Piotr Wiesiołek for almost two months. 
The provisions referring to the appointment of the President of the NBP can be found in art. 227 par. 3 of the Constitution in the wording "The President of the National Bank of Poland is appointed by the Seym at the request of the President of the Republic for 6 years", but also in the Act on the NBP in art. 9, where the question of appointing and dismissing the President of the NBP was concretised. It should be noted that regarding the term of office of the President of the NBP, European standards have been preserved in Polish law, because they require that the body be appointed for a minimum of five years and that the circumstances of its cancellation are strictly specified in the Act (Kłosiewicz, Szpringer, p. 278).

In the Act on NBP, there were provisions stating that the President of the NBP is appointed by the Seym at the request of the President of the Republic for six years, with the fact that the same person cannot perform this function for more than two consecutive terms. Therefore, you can be appointed for the post again, but after a break lasting a minimum of one term. It is worth adding that the Sejm decides to appoint the president of the NBP by an absolute majority of votes, so vote for a minimum of $50 \%+1$ vote in the presence of at least 231 deputies. The President of the NBP enters into his duties after submitting to the Seym an oath, the content of which is laid down in para. 3 art. 9 of the Act on the NBP, it reads as follows: "By taking over the duties of the President of the National Bank, I swear solemnly that I will strictly abide by the provisions of the Constitution and other laws and that in all my actions I will strive to develop my country's economic well-being and prosperity." An oath can be made of adding the words "So help me God."

After the six-year term of office of the President of the National Bank of Poland, the former President of the NBP performs his duties until the new President of the National Bank of Poland assumes the dutie However, if the term of office of the NBP President expires due to: death, resignation or dismissal, then the duties of the President of the NBP until the new President of the NBP assumes the duties, he is the vice-president of the NBP - first deputy NBP president. The NBP vice presidents are directed by the NBP work departments designated by the President of the NBP (Art. 10 item 3 NBP Act).

The subject of this Act is regulated in art. 9 par. 5. The NBP President may be dismissed only in the four circumstances specified in the Act - when 
the President of the NBP: does not fulfill his obligations as a result of longterm illness; has been convicted by a valid court sentence for the offense committed; has made a false statement on lustration, confirmed by a valid court decision; The Tribunal of State has ruled against him the prohibition of holding managerial positions or performing functions related to special responsibility in state bodies.

The regulations exhaustively define both cases of expiry of the term of office of the President of the NBP and dismissal from the position, which is to ensure the greatest possible freedom of decision regarding the monetary policy pursued (Świderska, p. 17). This is also related to the guarantee of NBP independence (Mikos-Sitek, Zapadka, p. 45). If any of the accidents being the basis for the NBP President's dismissal take place, the President should submit a motion to dismiss the President of the NBP to the Sejm, which is not directly implied by any of the provisions. In addition, the law does not indicate whose hands should be submitted resignation of the President of the NBP, although it seems that it should not be the President - who only submits the application for appointing the President of the NBP - and the Sejm, because he appoints the President of the National Bank of Poland (Kłosiewicz, Szpringer, p. 279).

The President of the National Bank of Poland is responsible for the organization and operation of the entire central bank. He is the superior of all NBP employees. He chairs the Monetary Policy Council, the NBP Management Board and represents the NBP outside. He represents the interests of the Republic of Poland in international banking institutions as well as in international financial institutions and sits as a member of the Financial Stability Committee (Art. 22a NBP Act) and the Polish Financial Supervision Authority (art. 5 par. 2 item 3 Supervision of the financial market Act).

The President of the NBP submits the application to the President for the appointment of NBP vice presidents and members of the NBP Management Board. In addition, the President of the NBP chairs the central bank bodies: the Monetary Policy Council and the NBP Management Board, but cannot impose their will on these bodies because they are collegial bodies and do not have to vote on the positions of the President of the NBP (in a vote on a given issue). However, it is particularly interesting that one NBP governing 
body is the leader of all the others. It seems that one can assume that the legislator creating the discussed solutions has been more focused on ensuring adequate coordination of the central bank than on adopting appropriate formal solutions (Niemierka, p. 9). However, it should be added that among the NBP bodies only the President of the NBP is legally liable to the Tribunal of State (Kosikowski, p. 15). Therefore, the President of the National Bank of Poland is the only body against which the law provides for bearing the most serious consequences in the form of constitutional liability.

In addition, the President of the National Bank of Poland: determines, in agreement with the minister responsible for internal affairs, the principles of storing monetary values in banks and enterprises producing money and transporting these values by banks and these enterprises and performs tasks resulting from the provisions on the general obligation to defend the Republic of Poland (art. 11 par. 5 NBP Act).

The President of the NBP may participate in meetings of the Sejm. He is obliged to cooperate with state authorities. The NBP President presents information and provides explanations regarding monetary policy and central bank's activities to the Sejm and Senate and their committees. On behalf of the Monetary Policy Council, which he chairs, he presents the Sejm and the Council of Ministers with information on the balance of payments and international investment position. In addition, on behalf of the Monetary Policy Council, it submits to the Council of Ministers and the Minister of Finance the draft monetary policy assumptions, opinions on the draft budget act, and the balance of payments forecast. In addition, it announces the discount and rediscount rate for promissory notes set by the council, interest rates on refinancing and lombard loans as well as mandatory reserves (Myślak, p. 94-95).

When issuing orders subject to publication and administrative decisions, the President of the National Bank of Poland has the right to use stamps with state emblems. It is authorized under the Act on the NBP to issue orders concerning (Mikos, p. 128): issue and withdrawal of currency; the rules and procedure for exchanging used cash; the rules and procedure for detaining suspicious signs of authenticity and dealing with counterfeit currency; rules for storing monetary values in banks and enterprises producing cash marks 
and for transporting these values by banks and these enterprises; and on the basis of the Banking Act (Journal of Law of 2012, item 1376 - ustawa z dnia 29 sierpnia 1997 r. Prawo bankowe) to issue orders regarding (Mikos, p. 128-129): the manner of performing interbank settlements, including by means of electronic data carriers; the manner and mode of conversion, sorting, packaging and marking of banknotes and coins, as well as performing activities related to supplying banks with these marks; numbering method of banks and their organizational units; the numbering method of bank accounts maintained at banks; determination of the value and terms of issue of bank securities for which the consent of the President of the National Bank of Poland is required (Niemierka, p. 9).

By introducing a new NBP body - the Monetary Policy Council - and changes to the Act on the NBP, the power of the President of the National Bank of Poland has been limited, and currently is mainly manifested in the management of other central bank bodies and the representative function.

\section{THE MONETARY POLICY COUNCIL}

the Monetary Policy Council (MPC) is a collegial body operating at the NBP only since 1998. Its creation was an expression of political and doctrinal compromise in the matter of establishing supervision over the functioning of the NBP. There are solutions known in the world that this supervision is exercised by an institution operating outside the central bank, not the body itself. In the matter of supervision over the Polish central bank, ideas deriving from this model were also presented. It was proposed to include in the Constitution a provision on the creation of a Banking Commission. This idea did not meet with approval. However, the limitation of the NBP President's powers in monetary policy matters was reflected in the MPC's (Myślak, p. 95-96), appointment, which took over the responsibilities of the NBP President and assesses the activities of the NBP Management Board in the implementation of its monetary policy guidelines, including the NBP President's activities as chairman of the Management Board.

The entry for the MPC was included in the Constitution in art. 227 par. 2. and in art. 6 of the Act on the NBP. Therefore, the MPC may be referred to as a "constitutional organ". The determination of the organization and tasks 
of this body found itself in the Constitution and in the Act on the NBP in art. 12-16, which indirectly indicates the role of the Monetary Policy Council in the performance of tasks by the NBP (Jończyk, p. 32). The first term of office of the MPC began in 1998, and subsequent in 2004, 2010 and 2016 (the term of office continues).

The composition of the MPC was specified in the Constitution in art. 227 par. 5, it includes: the President - ie the President - the National Bank of Poland and nine members. The MPC members are NBP employees employed on the basis of their appointment. They are entitled to a remuneration equal to the remuneration of the NBP vice-presidents. The Constitution requires the MPC members to be distinguished by their knowledge of finance. New members should be appointed at the latest on the expiry of the term of their predecessors. They are appointed in an equal number (three each) by the President of the Republic of Poland, the Sejm and the Senate. The term of office of the MPC, like the President of the National Bank of Poland, lasts 6 years, however, it cannot be repeated (art. 13 ust. 2 NBP Act.; Zob. również: Wyrok Trybunału Konstytucyjnego z dnia 24 listopada 2003 roku, K 26/03, OTK-A 2003, no 9, item 95, p. 8, upon: Wyrok TK).

Importantly, the legislator adopted the concept of individual term of office of individual MPC members and not the Council as a whole (Wyrok TK, p. 6-7). "Individualization of the term of office of the Council members, which in the future brings the effect of diversifying the moment of appointing individual members of the Council, ensures smooth exchange of MPC members and therefore guarantees its functional and institutional continuity (Wyrok TK, p. 7).

Authorities entitled to appoint a member of the Board shall only refer to him in the following five cases (art. 13 item 5 ustawy o NBP Act) (this directory seems not to be treated broadly) (Mikos, p. 93): renouncement of his function; a disease that permanently prevents the exercise of a function; conviction by a valid court sentence for committing a crime; submission of an untrue lustration declaration, confirmed by a valid court decision; not to become a member of a political party or a trade union for a period of office.

In the event of the death of a member of the Council, the appointing authority declares the expiration of his mandate. If the MPC member is 
dismissed or his mandate expires, the members appointing members complete the MPC composition not later than within 3 months of the vacant seat. However, the newly elected MPC member "does not complete" the tenure of the person for whose place he was appointed, and has his own 6-year term. In accordance with the 2003 ruling of the Constitutional Tribunal, as inconsistent with the constitutional regulation, the binding provisions of the Act - Art. 13 para. 7 sentence 2 - providing that the MPC members appointed as part of supplementing the MPC during its term of office perform their functions until the end of the term for which his predecessor was appointed. Therefore, the MPC members are always elected for an individual 6-year term (Wyrok TK, p. 8).

A member of the Board before taking up duties in the Council shall file before the appointing authority, enshrined in art. 13 para. 4 of the Act on the NBP, the following oath: "By taking over the duties of a member of the Monetary Policy Council, I swear solemnly that I will act with impartiality, knowledge and experience in the field of monetary policy, in accordance with the objectives of the National Bank of Poland." The oath can be made with the addition of the words "So help me God."

During the term of office, members of the Monetary Policy Council may not occupy any other positions and undertake commercial or public activities. However, the Act on the NBP lists in art. 14 par. 1 classes that can be undertaken by the MPC members are: scientific and didactic work and author's creation. It also indicates activities in international organizations, but here it is required by the MPC consent expressed in a resolution.

Monetary Policy Council in accordance with art. 12 of the Act on the NBP:

- sets the monetary policy assumptions every year and submits them to the Sejm for information at the same time as the draft budget bill is submitted by the Council of Ministers;

- submits to the Sejm a report on the implementation of the monetary policy guidelines within 5 months from the end of the budget year;

- determines the level of NBP interest rates;

- sets the reserve requirement rates of banks and cooperative savings and credit unions and the amount of its interest rate;

- sets the upper limits of liabilities resulting from the NBP taking loans and credits from foreign banking and financial institutions; 
- approves the financial plan of the NBP and the report on the activities of the NBP;

- accepts the annual financial report of the National Bank of Poland;

- sets out the rules for open market operations;

- performs evaluations of the activities of the NBP Management Board in the implementation of monetary policy assumptions.

In addition, the Monetary Policy Council may, in the event of a threat to the implementation of monetary policy, introduce by way of a resolution: limiting the amount of funds deposited by banks to the disposal of borrowers and borrowers. It may also introduce the obligation to maintain a noninterest-bearing deposit with the NBP on foreign funds used by banks and domestic entrepreneurs (art. $46 \mathrm{NBP}$ Act). It is worth noting that the last two powers - which can be called extraordinary means - have so far not been exercised by this body (Mikos, p. 129).

As a collegiate body, the MPC makes decisions at meetings which are convened by the chairman of the Monetary Policy Council at least once a month. A meeting of the MPC may also be convened on a written request of at least three MPC members. The vice presidents of the NBP participate in the meetings of the Council without the right to vote (art. 15 NBP Act). The mode of operation of the MPC is set out in the regulations adopted by the Council by a majority of votes. The MPC adopts resolutions by a majority of votes in the presence of at least 5 members, including the Chairman of the Council. In the event of an equal number of votes, the vote of the Chairman of the Supervisory Board is decisive. What is important, the positions taken by the members of the Board in the vote are subject to announcement in "Monitor Sądowy i Gospodarczy" after 6 weeks, but not later than 3 months from the date of adoption of the resolution (art. 16 NBP Act).

As previously mentioned, the Monetary Policy Council performs evaluations of the activities of the NBP Management Board in the implementation of the assumptions of its monetary policy. "The Monetary Policy Council, which sets the monetary policy assumptions, is not subject to assessment by other NBP bodies or by state authorities and is not liable for the shape of monetary policy. The Monetary Policy Council may negatively 
assess the activities of the NBP Management Board in the implementation of monetary policy assumptions, including the activities of the President of the NBP as the chairman of the NBP Management Board. The NBP Management Board does not assess the activities of other NBP bodies" (Kosikowski, p. 15). Relations between NBP authorities regarding legal liability for the NBP's activities are considered incorrect.

As previously mentioned, the MPC members are NBP employees. In the literature one may encounter the thesis that this may be the reason for the dependence of the MPC members on the President of the National Bank of Poland, who acts as their chairman. This would cast doubt on the objective performance of certain obligations by the Monetary Policy Council. In particular, the NBP Management Board's assessment of the implementation of monetary policy objectives (Myślak, p. 76).

\section{THE MANAGEMENT BOARD OF THE NBP}

The NBP Management Board is responsible for managing the day-to-day operations of the central bank. This is the executive body of the National Bank of Poland. The Constitution mentions only that it is the body of the National Bank of Poland. And the Act on the NBP in art. 17-20 defines the mode of appointing its members and indicates their tasks. The NBP Management Board consists of the President of the NBP - as chairman and 6-8 members of the Management Board, including 2 NBP vice presidents. Members of the NBP Management Board and vice presidents are appointed and dismissed by the President at the request of the President of the National Bank of Poland. New members should be appointed at the latest on the expiry of the term of their predecessors. The term of office of the members of the NBP Management Board, as well as the President of the National Bank of Poland and the Monetary Policy Council, lasts 6 years. The same person cannot be a member of the NBP Management Board for more than two consecutive terms.

Circumstances in which the President - as being the governing body of members of the NBP Management Board - may dismiss a member of the NBP Management Board are analogous to those in which the appointing authority has the right to dismiss members of the Monetary Policy Council, so it can only take place in the following five cases (art. 13 item 5 NBP Act): a waiver of 
his function; a disease that permanently prevents the exercise of a function; conviction by a valid court sentence for committing a crime; submitting an untrue lustration declaration, confirmed by a valid court decision; not to perform activities in a political party or in a trade union for the term of office.

In the event of the death of a member of the NBP Management Board, the President shall declare the expiration of his mandate. Both in the event of dismissal of a member of the NBP Management Board for the abovementioned reasons and the expiration of his mandate, the President shall supplement the composition of the NBP Management Board no later than within 3 months of the release of the seat.

During the term of office, members of the NBP Management Board - just like the MPC members - cannot occupy any other positions and undertake commercial or public activity outside of academic, didactic or author's work. As mentioned earlier, the activity of the NBP Management Board is subject to review by the MPC, which issues resolutions in this respect.

The NBP Management Board implements resolutions of the Council and adopts its own resolutions on matters not reserved in the Act to the exclusive competence of other NBP bodies, mainly regarding the launch of operational activities related to the implementation of the monetary policy guidelines set by the Monetary Policy Council (art. 17 item. 3 NBP Act). The scope of activities of the NBP Management Board includes in particular:

- implementation of tasks in the field of exchange rate policy (including exchange rates of foreign currencies expressed in zlotys) (Mikos, p. 129);

- periodic assessment of the monetary and monetary settlements and foreign exchange transactions;

- supervision of open market operations;

- assessment of the banking system functioning;

- analysis of the stability of the domestic financial system;

- adoption of the NBP's business plan and financial plan;

- adopting banking commissions and bank fees and determining their amount;

- determining the principles of managing the NBP funds;

- defining the principles of organization and division of tasks at the NBP;

- determining the principles of HR and payroll policy at the NBP; 
- adoption of the annual report on the activities of the NBP;

- drawing up the NBP's annual financial report;

- preparing balances of foreign currency payments of the country;

- preparation and consideration of draft resolutions and other materials addressed to the Monetary Policy Council.

Included in art. $17 \mathrm{sec} .4$ of the Act on the National Bank of Poland, the list of activities of the NBP Management Board is not closed, as indicated by the phrase "in particular" and the provision that the NBP Management Board adopts its own resolutions in matters not reserved in the Act to the exclusive competence of other NBP bodies. It should be added that it adopts resolutions regulating the NBP's internal activities, which are addressed to the organizational units of the NBP and only they are required to perform them.

In addition, the NBP Management Board, based on the Act on the NBP, is authorized to (Mikos, p. 129-130):

- determining the rules and procedure for calculating and maintaining mandatory reserves at the NBP, including bank accounts which are not subject to the obligation to maintain reserves, and may also specify the amount of cash in PLN, whose maintenance at bank vaults will be tantamount to maintaining reserves at the NBP, also the rules for calculating the interest rate on the required reserve and the transfer of funds due from this interest rate,

- determination of the interest rate on the difference in obligatory reserve,

- determining the types of bills of exchange accepted by the NBP for discount and rediscount as well as the rules and procedures for their discount and rediscount,

- determining the conditions for opening and maintaining bank accounts by the NBP.

Regarding the function of the NBP Management Board, it is worth quoting Professor Cezary Kosikowski's statement: "by comparing the tasks of the NBP as the central bank of the state with the catalogs of tasks and competences of 
the NBP bodies, it can be stated that the performance of certain NBP tasks has not been explicitly" assigned "to any the NBP body. With the legislative technique used in the Act on the NBP to determine the tasks and powers of the NBP's bodies, this means that these are not the tasks and competences of the Monetary Policy Council or the President of the NBP" (Kosikowski, p. 15). Therefore, there are a number of NBP tasks that belong to the NBP Management Board, but are not directly listed in the Acts.

The mode of operation of the NBP Management Board is defined in the regulations adopted by the NBP Management Board by a majority of votes (art. $20 \mathrm{NBP}$ Act). This body adopts resolutions by an absolute majority of votes (art. 19 NBP Act).. In the event of an equal number of votes, the vote of the chairman of the NBP's Management Board, the President of the NBP, is decisive. In addition to the resolutions, it also issues provisions that mainly concern internal management. Here, as in the case of resolutions, the absolute majority of votes is decisive, and in the situation of an equal number of votes, the vote of the chairman of the NBP Management Board is decisive. The regulations of the NBP Management Board include the special procedure for considering the draft resolutions and provisions. This is called the circulation mode, where decisions are made by way of correspondence arrangements. This procedure is activated in explicit cases of urgency, previously discussed at the meetings of the NBP Management Board and in matters of lesser importance (Myślak, p. 103).

\section{CONCLUSion}

in its long history, the Polish central bank has become a bank not only independent, but also meeting European standards, manifesting itself even in the term of office of the President of the National Bank of Poland, or in compliance with the principles of accounting. The institution has three basic roles: a state bank, an issuing bank and a bank of banks. In particular, the scope of his competences includes shaping and implementing monetary policy, which the National Bank of Poland does independently. Because it is his body - the Monetary Policy Council - that every year he set monetary policy and submits it - only to the Sejm. In addition, the organs of this major financial institution cooperate in shaping and conducting Polish foreign 
exchange policy: the NBP Management Board conducts periodic reviews of monetary and monetary settlements and foreign exchange transactions, while the Monetary Policy Council determines the upper limits of liabilities resulting from borrowing loans and bank loans from foreign banking institutions and the President of the NBP has the competence to decide on the granting of an individual foreign exchange permit. The National Bank of Poland also deals with the maintenance of bank accounts, including the state budget account, banks, the Bank Guarantee Fund, the National Cooperative Savings and Credit Union. In addition, he runs his own financial management having financial privileges and a bankruptcy privilege.

\section{References}

(Journal of Law of 1952, no 33, item 232) Konstytucja Polskiej Rzeczypospolitej Ludowej uchwalona przez Sejm Ustawodawczy.

(Journal of Law of 1992, no 84, item 426) - ustawa konstytucyjna z dnia 17 października 1992 r. o wzajemnych stosunkach między władzą ustawodawczą i wykonawczą Rzeczypospolitej Polskiej oraz o samorządzie terytorialnym.

(Journal of Law of 1997, no 78, item 483) - Konstytucja Rzeczypospolitej Polskiej z dnia 2 kwietnia 1997 r. uchwalona przez Zgromadzenie Narodowe w dniu 2 kwietnia 1997 r., przyjęta przez Naród w referendum konstytucyjnym w dniu 25 maja 1997 r., podpisana przez Prezydenta Rzeczypospolitej Polskiej w dniu 16 lipca 1997 r.

(Journal of Law of 2012, item 1376) - ustawa z dnia 29 sierpnia 1997 r. Prawo bankowe.

Wyrok Trybunału Konstytucyjnego z dnia 24 listopada 2003 roku, (K 26/03, OTK-A 2003, no 9, item 95).

Jończyk A., (1998). Rada Polityki Pieniężnej nowy organ banku centralnego, Przegląd Podatkowy 1998, no 8. ISSN 0867-7514.

Kosikowski C., (1997). Gospodarka i finanse publiczne w nowej Konstytucji, Państwo i Prawo 1997, no 11. ISSN 0031-0980.

Kosikowski C., (2002). Pozycja Narodowego Banku Polskiego i jego organów w prawie polskim (stan obecny i postulaty na przyszłość), Państwo i Prawo 2002, no 11. ISSN 0031-0980.

Kłosiewicz P., (1999). W. Szpringer, Zarzadzanie Bankiem Centralnym w świetle nowej ustawy o Narodowym Banku Polskim, Glosa 1997, nr 11 [In:] C. Kosikowski, Publiczne prawo bankowe, Warszawa: Polskie Wydawnictwo Ekonomiczne. ISBN 832081216X. 
Mikos A., (2006). Ustrojowa pozycja banku centralnego w Polsce, Warszawa: Wydawnictwo C.H.Beck. ISBN 9788374831512.

Mikos-Sitek A., (2011). Zapadka P., Polskie Prawo Bankowe. Wybrane zagadnienia, Warszawa: Wolters Kluwer Poska. ISBN 9788326416132.

Myślak E., (2013). Narodowy Bank Polski w systemie ustrojowym Rzeczypospolitej Polskiej, Kraków: Wydawnictwo Uniwersytetu Jagielońskiego. ISBN 9788323335634.

Niemierka S., (1998). Pozycja Prezesa NBP w „ustawach bankowych”, Glosa 1998, no 8, p. 9.

Świderska J. (ed.), (2010). Bank Centralny w Polsce. Wybrane aspekty, Warszawa: Difin. ISBN 9788376413501.

Tupin R., (2001). Sprawa nadrzędna gospodarka, Rzeczpospolita 2001, no 11. ISSN 0208-9130.

Tupin R., (1998). Status prawny i kompetencje prawotwórcze organów Narodowego Banku Polskiego i Komisji Nadzoru Bankowego, Przegląd Ustawodawstwa Gospodarczego 1998, no 7-8. ISSN 01347-5490.

Zubik M., (2001). Narodowy Bank Polski (analiza konstytucyjno-ustrojowa), Państwo i Prawo 2001, no 6. ISSN 0031-0980. 